\title{
Epidemiological profile of Brazilian oncological patients seen by a reference oncology center of the public health system and who migrate in search of adequate health care
}

\author{
(iD) Daniel I.G. Cubero ${ }^{1}$ \\ Cláudia Vaz de Melo Sette \\ Beatriz de Camargo Preto Piscopo ${ }^{1}$ \\ Camila Ribeiro de Arruda Monteiro ${ }^{1}$ \\ Jean Henri Maselli Schoueri ${ }^{1}$ \\ Heloísa Duarte de Andrade Tavares ${ }^{1}$ \\ Igor Luiz Argani ${ }^{1}$ \\ Marilia Arrais Garcia ${ }^{1}$ \\ Karoline Passarela ${ }^{1}$ \\ Auro del Giglio'
}

1. ABC School of Medicine (Faculdade de Medicina do ABC - FMABC), Santo André, São Paulo, Brasil

http://dx.doi.org/10.1590/1806-9282.64.09.814

\section{SUMMARY}

INTRODUCTION: Structural disparities between different Brazilian regions in public health system cause patients to migrate in search of better conditions to treat their diseases. Besides patient's discomfort, there is a concentration of care in large centres, causing overload to current capacity.

OBJECTIVE: To evaluate migratory flow and associated factors in a reference service in oncology.

METHODS: Cross-sectional study conducted at a referral oncology service in Great ABC region of São Paulo. Patients were interviewed, and clinical and demographic data collected.

RESULTS: Between March-July 2016, 217 patients were included. Analysis showed a divergence between the postal code registered in the medical record and that recorded during the interview in approximately 10\% of cases. Of these, $42.9 \%$ were residents of other states. Search for treatment motivated most patients to seek service outside their city.

CONCLUSION: Results reflect the informal search for medical care outside the home area. Besides the direct impact on patients' quality of life, migratory flow has an economic-social impact because these patients place a burden and impose costs on services of cities where they do not perform their responsibilities as citizens. Confirmation of the existence of a significant migratory flow demonstrates the need to discuss restructuring public health policies.

KEYWORDS: Human migration. Neoplasms. Health services accessibility. Health policy. 


\section{INTRODUCTION}

Brazil displays large socioeconomic differences between states and cities. ${ }^{1}$ However, the Federal Constitution guarantees, through the principle of Universality of the Unified Health System (Sistema Único de Saúde - SUS), that all Brazilian citizens have the right to access health services and actions. ${ }^{2-4}$. Furthermore, the principles of hierarchization and regionalization demonstrate that those services offered must be organized at levels of increasing technological complexity, arranged in a defined geographical area and defined by the population to be served. ${ }^{3}$

In practice, the socioeconomic disparities between the different regions of the country ${ }^{1}$ lead some users of the system to seek more complex and quality care away from their homes, particularly regarding diseases that require complex, costly, and prolonged treatments, such as cancer. However, there is no data in the Brazilian literature that express this occurrence.

Thus, the present study aimed to measure the actual migratory rate of patients, who informally sought medical care outside their residential area, present at a reference centre for cancer treatment.

\section{OBJECTIVES}

To evaluate the migratory flow of patients to a reference centre in oncology.

\section{METHODS}

This cross-sectional study was performed at the oncology department of the Padre Anchieta Teaching Hospital (Hospital de Ensino Padre Anchieta) in São Bernardo do Campo. This study was approved by the Institution's Research Ethics Committee prior to beginning the research - Certificate of Presentation for Ethical Appreciation (CAAE), number: 54167116.8.0000.0082. The participants signed an informed consent form (termo de consentimento livre esclarecido - TCLE), and the confidentiality of the data collected was assured.

Oncology patients who had over 18 years old and received treatment or follow-up participated in the study. Patients who did not understand the nature and procedures of the research were excluded.

For data collection, patients were interviewed using Form 1 (attached). Next, their respective charts were analysed, and their postal code (Código de Endereçamento Postal - CEP) reported in the interview was compared to that reported in the system/medical records.

\section{STATISTICAL ANALYSIS}

The sociodemographic data collected from the studied population was described in terms of their relative and absolute frequencies. The association between categorical variables was verified by chisquare test. For associations with values less than 5 , Fisher's exact test was used. The statistical program used was Stata ${ }^{\circledR}$, version 12.1.

\section{RESULTS}

From March to July 2016, a total of 217 patients were included, of which 134 (61.7\%) were female. The median age was 59.7 years old, ranging from 20 to 89 years. Regarding marital status, the two most frequent categories were married and single, with 119 (54.8\%) and 41 (18.9\%) individuals, respectively. Most patients (63.6\%) were individuals with little education, up to only elementary school. The family income of $86.6 \%$ of individuals was limited to three minimum wages (approximately USD 1,000), and the majority (93.6\%) did not have health insurance. Among the patients who had health insurance (corresponding to only 14 patients in this sample), 78.6\% used it to complete part of the treatment. Table 1 shows the sociodemographic data of the studied population.

The CEP analysis showed that there was a divergence between the CEP recorded in the medical record and that declared by the patient during the interview in approximately $10 \%$ (21) of the cases. Of these, 17 (81\%) lived with a relative, and the search for treatment was the main reason for the change in postal code (66.7\%). Of the patients who migrated, $42.8 \%$ were from non-ABC cities in the state of São Paulo, $42.8 \%$ were from other states, and the remainder (14.3\%) were from the Great ABC. There was no relationship between the educational level or the primary tumour location and the migration rate. Table 2 summarizes the characteristics found among the patients who migrated.

In the exploratory analysis of possible factors contributing to or associated with migration in search of treatments, no statistically significant relationships 
TABLE 1: SOCIODEMOGRAPHIC DATA

\begin{tabular}{|c|c|c|c|}
\hline & & $\begin{array}{l}N= \\
217\end{array}$ & $100 \%$ \\
\hline \multirow[t]{2}{*}{ Gender } & Female & 134 & $61.7 \%$ \\
\hline & Male & 83 & $38.3 \%$ \\
\hline \multirow[t]{2}{*}{ Age } & Median & \multicolumn{2}{|c|}{59.7 years } \\
\hline & Interval & \multicolumn{2}{|c|}{20 to 89 years } \\
\hline \multirow[t]{3}{*}{ Marital Status } & Single & 41 & $18.9 \%$ \\
\hline & Married & 119 & $54.8 \%$ \\
\hline & Other & 57 & $26.3 \%$ \\
\hline \multirow[t]{4}{*}{ Education } & Illiterate & 14 & $6.4 \%$ \\
\hline & Elementary school & 138 & $63.6 \%$ \\
\hline & High school & 52 & $24 \%$ \\
\hline & Higher education & 13 & $6 \%$ \\
\hline \multirow[t]{2}{*}{ Income } & Up to 3 minimum wages & 188 & $86.6 \%$ \\
\hline & $\begin{array}{l}4 \text { minimum wages or } \\
\text { more }\end{array}$ & 29 & $13.4 \%$ \\
\hline \multirow[t]{2}{*}{ Has insurance } & Yes & 14 & $6.4 \%$ \\
\hline & No & 203 & $93.6 \%$ \\
\hline \multirow{2}{*}{$\begin{array}{l}\text { Uses insurance as } \\
\text { part of the treat- } \\
\text { ment }\end{array}$} & Yes & 11 & $78.6 \%$ \\
\hline & No & 3 & $21.4 \%$ \\
\hline \multirow[t]{4}{*}{ Religion } & Catholic & 135 & $62.2 \%$ \\
\hline & Evangelical & 62 & $28.6 \%$ \\
\hline & Other & 14 & $6.4 \%$ \\
\hline & No religion & 6 & $2.8 \%$ \\
\hline $\begin{array}{l}\text { Primary tumor } \\
\text { location }\end{array}$ & $\begin{array}{l}\text { Breast } \\
\text { Gastrointestinal tract } \\
\text { Gynecological } \\
\text { Genitourinary tract } \\
\text { Other }\end{array}$ & $\begin{array}{l}61 \\
59 \\
25 \\
22 \\
49\end{array}$ & $\begin{array}{l}28.2 \% \\
27.3 \% \\
11.6 \% \\
10.2 \% \\
22.7 \% \\
\end{array}$ \\
\hline \multirow[t]{4}{*}{ City of origin } & São Bernardo do Campo & 160 & $73.7 \%$ \\
\hline & Great $A B C$ & 36 & $16.6 \%$ \\
\hline & Other cities (SP) & 12 & $5.5 \%$ \\
\hline & Other states & 9 & $4.2 \%$ \\
\hline
\end{tabular}

TABLE 2: SOCIODEMOGRAPHIC DATA OF PATIENTS WHO MIGRATE

\begin{tabular}{l|l|l|l}
\hline Lives with family & Yes & $\begin{array}{l}\mathrm{N}=21 \\
17\end{array}$ & $\begin{array}{l}100 \% \\
81 \%\end{array}$ \\
\cline { 2 - 4 } & No & 4 & $19 \%$ \\
\hline \multirow{2}{*}{ Reason for change } & Search for treatment & 14 & $66.7 \%$ \\
\cline { 2 - 4 } & Family company & 4 & $19 \%$ \\
\cline { 2 - 4 } & Other & 3 & $14.3 \%$ \\
\hline City of origin & Great ABC & 3 & $14.3 \%$ \\
\cline { 2 - 4 } & $\begin{array}{l}\text { Other cities in the } \\
\text { state of São Paulo }\end{array}$ & 9 & $42.8 \%$ \\
\cline { 2 - 4 } & Other states & 9 & $42.8 \%$ \\
\hline \multirow{2}{*}{$\begin{array}{l}\text { Got treatment in } \\
\text { the city of origin }\end{array}$} & Yes & No & $\begin{array}{l}38.1 \% \\
61.9 \%\end{array}$ \\
\hline
\end{tabular}

TABLE 3 - ASSOCIATIONS BETWEEN SOCIOECONOMIC CHARACTERISTICS AND MIGRATION

\begin{tabular}{|c|c|c|c|c|}
\hline & & $\begin{array}{l}\text { Migra- } \\
\text { tion } \\
\text { No }\end{array}$ & $\begin{array}{l}\text { Migra- } \\
\text { tion Yes }\end{array}$ & $\begin{array}{l}\text { Chi }{ }^{2} \text { Test / } \\
\text { Fisher's * } \\
\mathrm{p}\end{array}$ \\
\hline \multirow[t]{2}{*}{ Education } & $\begin{array}{l}\text { Up to elemen- } \\
\text { tary school }\end{array}$ & 139 & 13 & \multirow[t]{2}{*}{0.391} \\
\hline & $\begin{array}{l}\text { High school or } \\
\text { higher educa- } \\
\text { tion }\end{array}$ & 57 & 8 & \\
\hline \multirow[t]{2}{*}{ Income } & $\begin{array}{l}\text { Up to } 3 \text { mini- } \\
\text { mum wages }\end{array}$ & 168 & 20 & \multirow[t]{2}{*}{$0.322^{*}$} \\
\hline & $\begin{array}{l}4 \text { or more mini- } \\
\text { mum wages }\end{array}$ & 28 & 1 & \\
\hline \multirow{4}{*}{$\begin{array}{l}\text { Date of diag- } \\
\text { nosis }\end{array}$} & Up until 2012 & 44 & 4 & $1.000^{\star}$ \\
\hline & After 2012 & 151 & 17 & \\
\hline & Breast & 59 & 2 & \\
\hline & Gastrointestinal & 52 & 7 & \\
\hline \multirow[t]{3}{*}{$\begin{array}{l}\text { Location of pri- } \\
\text { mary neoplasm }\end{array}$} & $\begin{array}{l}\text { Gynecological } \\
\text { tract }\end{array}$ & 25 & 0 & $0.036^{\star}$ \\
\hline & $\begin{array}{l}\text { Genitourinary } \\
\text { tract }\end{array}$ & 18 & 4 & \\
\hline & Other & 41 & 8 & \\
\hline
\end{tabular}

were observed regarding the divergence between CEPs and schooling or family income level. However, the primary location of the disease was related to the migratory process (Table 3).

\section{DISCUSSION}

This study was performed in a reference centre for oncology in the Great $\mathrm{ABC}$, which is a region composed of seven cities that together total over 2.5 million inhabitants. ${ }^{5}$ Regarding the included subjects, it is important to mention that, although the exact amount of patients that have been attended by the Hospital has not been recorded, the inclusion of 217 subjects is in accordance to what has been previously stipulated to be a suitable sample for this article.

Of the patients seen in the service, $73.7 \%$ live in São Bernardo do Campo (the city where the service is established), whereas $16.6 \%$ live in other cities of the Great ABC, which is not defined by migration because the hospital in question is a regional reference centre.

However, approximately $10 \%$ of the patients seen do not live effectively at the addresses provided in the hospital registry, and $42.8 \%$ of those patients do not even live in the state of São Paulo. We also noted a significant difference regarding the location of the primary tumour presented in patients who migrated as compared with those who did not. For example, 
regarding those who did not migrate, 59 out of 195 patients (approximately 30\%) had Breast Cancer, while it corresponds to roughly 10\% (2 out of 21 patients) of those who did migrate. On the other hand, the proportion of those who did not migrate versus those who did goes up to approximately $26 \%$ (52 patients) and 33\% (7 patients), respectively, for those patients who had Gastrointestinal tumours. We believe that these differences may be due to the higher complexity of the care of some types of tumours such as those of GI origin as compared with breast primaries. Interestingly, Athanasakis et al. ${ }^{6}$ mentions that more severe cases tend to migrate hoping for better healthcare services, whereas benign cases tend to stay where they reside. Whether to get treatment or to be close to their relatives, these patients left their homes, characterizing the process of informal migration.

This problem is not restricted to Brazil. In Greece, where there is a health system similar to SUS, a study showed a migratory flow equivalent to $13.4 \%$ of all cancer patients in the country in search for better treatment. ${ }^{6}$ In addition, a Canadian study has shown that moving to receive oncological treatment has significant economic impacts, in addition to presenting biopsychosocial sequelae for both the patient and his/her caregivers. ${ }^{7}$

Although frequent, there are few studies in the literature addressing this issue. Some papers on the subject worldwide have shown the inequality of cancer treatment access in different countries resulting in a migration process, but do not seem to have reached consensus on the motivations for this migration nor do they agree on the consequences for citizens, although it appears to be harmful. ${ }^{8-12}$ The present study showed that about $10 \%$ of patients treated in a cancer centre in Brazil were from different regions of the country, demonstrating a social health problem.

The description of the phenomenon of migration in different countries, with different levels of development and distinct cultures, points to the universal problem of inequality between regions of the same country. The origin of the problem may lie in the concentration of wealth in some regions to the detriment of others, which is reflected in the health area. ${ }^{1}$ As in previous studies, our results show non-compliance with SUS principles. ${ }^{13}$

The fact that someone who does not live in a certain city intends to live in that municipality so he/she can use its health system is alarming. This causes a cost to that city that was not foreseen in its budget and is a burden to the system, which was not designed to receive an extra number of patients.

Thus, a potential proposal is the creation of a single register for the citizen. The single register would allow the exercise of citizenship, such as the vote in the municipal elections and taxes payment, to be linked to the municipality where the individual lives. The single register could avoid forging documentation and/or providing false home address data, thus avoiding the services burden, both economically and physically.

\section{LIMITATIONS OF THE STUDY}

Although other studies relate the socioeconomic condition to the migration process, this relationship was not statistically relevant in our study..$^{14}$ However, the study in question was performed in a single centre of reference, reflecting the migratory flow existing only in this region and for a specific specialty (oncology). Overall, more comprehensive national data involving multiple reference centres in oncology could provide more accurate information. The same methodology could be used for other specialties.

\section{CONCLUSION}

In the present study we found a migration rate of approximately $10 \%$ of patients interviewed, which demonstrates the inequalities in the supply of health services in SUS. Because this situation can have a strong economic and social impact on both the individual need for migration among cancer patients and the municipality, the study in question highlights the need for extending more complex oncological therapies to larger parts of the Country to further decrease human migration.

\begin{tabular}{l} 
Summary Box \\
\hline What is already known on this subject? \\
\hline $\begin{array}{l}\text { It is already known that socioeconomic disparities between regions } \\
\text { of the same country lead to people searching for more complex } \\
\text { treatments away from their homes }\end{array}$ \\
\hline What does this study add? \\
\hline $\begin{array}{l}\text { The study adds data regarding the Brazilian reality on this topic, } \\
\text { showcasing its occurrence on a reference centre for cancer treat- } \\
\text { ment }\end{array}$ \\
\hline $\begin{array}{l}\text { It also highlights the need for restructuring public health policies } \\
\text { in Brazil }\end{array}$
\end{tabular}




\section{Data Sharing Statement}

There is no additional data to be shared.

\section{Funding and Conflicts of interest}

There was no funding for this research. The authors declare not having any conflicts of interest regarding this paper.

\section{Author contribution}

Regarding the author's participation in the present study, we declare that:

1) All authors have equally contributed to this paper and data gathering;
2) Authors Daniel Cubero, Claudia Sette and Auro del Giglio were responsible for the supervision of the research and the statistical analysis review;

3) Authors Beatriz Piscopo, Camila Monteiro, Jean Schoueri and Igor Argani were assigned the methodology, review and final writing of the Manuscript;

4) Authors Heloísa Tavares, Marília Garcia and Karoline Passarela were responsible for the initial writing of the paper.

Therefore, all authors have intellectually contributed to the present research.

\section{RESUMO}

INTRODUÇÃO: As disparidades estruturais entre diferentes regiões brasileiras no sistema de saúde pública fazem com que os pacientes migrem em busca de melhores condições para tratar suas doenças. Além do desconforto do paciente, há uma concentração de cuidados em grandes centros, causando sobrecarga da capacidade atual.

OBJETIVO: Avaliar o fluxo migratório e fatores associados em um serviço de referência em oncologia.

MÉTODOS: Estudo transversal realizado em um serviço de oncologia de referência na região do Grande ABC, em São Paulo. Os pacientes foram entrevistados e dados clínicos e demográficos coletados.

RESULTADOS: Entre março e julho de 2016 foram incluídos 217 pacientes. A análise mostrou uma divergência entre o código de endereçamento postal registrado no prontuário médico e o registrado durante a entrevista em aproximadamente 10\% dos casos. Desses, 42,9\% eram residentes de outros estados. A busca de tratamento motivou a maioria dos pacientes a buscar serviços fora de sua cidade. CONCLUSÃo: Os resultados refletem a busca informal de cuidados médicos fora da área de residência. Além do impacto direto na qualidade de vida dos pacientes, o fluxo migratório tem um impacto econômico-social porque esses pacientes colocam um fardo e impõem custos aos serviços das cidades onde não executam suas responsabilidades como cidadãos. A confirmação da existência de um fluxo migratório significativo demonstra a necessidade de discutir a reestruturação das políticas de saúde pública.

PALAVRAS-ChaVE: Migração humana. Neoplasias. Acesso aos serviços de saúde. Política de saúde.

\section{REFERENCES}

1. Szwarcwald CL, Souza únior $P R$, Marques $A P$, Almeida WD, Montilla DE. Inequalities in healthy life expectancy by Brazilian geographic regions: findings from the National Health Survey, 2013. Int | Equity Health. 2016;15(1):141

2. Pontes AP, Oliveira DC Gomes AM. The principles of the Brazilian Unified Health System, studied based on similitude analysis. Rev Lat Am Enfermagem. 2014;22(1):59-67.

3. Brasil. Ministério da Saúde. Secretaria Nacional de Assistência à Saúde ABC do SUS: doutrinas e princípios. Brasilia: Ministério da Saúde; 1990.

4. Brasil. Constitution of Brazil. [accessed on: 1 August 2017]. Available from http://www.refworld.org/docid/4c4820bf2.html

5. Brasil. IBGE. [Accessed on: 27 April 2017]. Available from: http://cidades ibge.gov.br/

6. Athanasakis K, Souliotis K, Kyriopoulos E), Loukidou E, Kritikou P, Kyriopoulos J. Inequalities in access to cancer treatment: an analysis of cross-regional patient mobility in Greece. Support Care Cancer 2012;20(3):455-60

7. Lightfoot N, Steggles S, Gauthier-Frohlick D, Arbour-Gagnon R, Conlon $M$, Innes C, et al. Psychological, physical, social, and economic impact of travelling great distances for cancer treatment. Curr Oncol. 2005;12(4):1-7.
8. Rosato R, Sacerdote C, Pagano E, Di Cuonzo D, Baldi I, Bordon R, et al. Appropriateness of early breast cancer management in relation to patient and hospital characteristics: a population-based study in Northern Italy. Breast Cancer Res Treat. 2009;117(2):349-56.

9. Dejardin $O$, Remontet L, Bouvier AM, Danzon A, Trétarre B, Delafosse P; et al. Socioeconomic and geographic determinants of survival of patients with digestive cancer in France. Br J Cancer. 2006;95(7):944-9.

10. Jack RH, Gulliford MC, Ferguson I, Møller $\mathrm{H}$. Geographical inequalities in lung cancer management and survival in South East England: evidence of variation in access to oncology services? Br J Cancer. 2003;88(7):1025-31.

11. Sariego J. Patterns of breast cancer presentation in the United States: does geography matter? Am Surg. 2009;75(7):545-9.

12. Sariego I. Regional variation in breast cancer treatment throughout the United States. Am J Surg. 2008;196(4):572-4.

13. Radaelli RG; Medeiros CRG. Rede de Cuidados em Oncologia: trajetórias assistenciais como ferramenta avaliadora da integralidade e do acesso. Caderno Pedagógico. 2015;12(1):277-88.

14. Mandelblatt JS, Yabroff KR, Kerner JF. Equitable access to cancer services: A review of barriers to quality care. Cancer. 1999;86(11):2378-90. 